

http://www.e-journals.net
ISSN: 0973-4945; CODEN ECJHAO

E-Journal of Chemistry

Vol. 5, No. 1, pp. 130-135, January 2008

\title{
Syntheses and Characterization of Some Tetradentate Schiff-Base Complexes and Their Heteroleptic Analogues
}

\author{
A. A. OSOWOLE \\ Department of Chemistry, \\ University of Ibadan, Ibadan, Nigeria. \\ aderoju30@yahoo.com
}

Received 6 June 2007; Accepted 22 July 2007

\begin{abstract}
VO}(\mathrm{IV}), \mathrm{Ni}(\mathrm{II})$ and $\mathrm{Cu}(\mathrm{II})$ complexes of the asymmetric Schiff base $\left[\left(\mathrm{HOC}_{6} \mathrm{H}_{3}\left(\mathrm{OCH}_{3}\right) \mathrm{C}\left(\mathrm{C}_{6} \mathrm{H}_{5}\right): \mathrm{N}\left(\mathrm{CH}_{2} \mathrm{CH}_{2}\right) \mathrm{N}: \mathrm{C}\left(\mathrm{CH}_{3}\right) \mathrm{CH}: \mathrm{C}\left(\mathrm{C}_{6} \mathrm{H}_{5}\right) \mathrm{OH}\right)\right]$, and their heteroleptic analogues with triphenyl phosphine and 2,2'-bipyridine have been synthesized and characterized by elemental analyses, conductance, magnetic, infrared and electronic spectral measurements. The ligand is tetradentate coordinating via the imine $\mathrm{N}$ and enolic $\mathrm{O}$ atoms. The $\mathrm{Ni}$ (II) and $\mathrm{Cu}(\mathrm{II})$ complexes adopt a four coordinate square planar geometry, the VO(IV) complex is five coordinate square-pyramidal and the heteroleptic complexes are 6-coordinate, octahedral. The assignment of geometry is collaborated by magnetic moments and electronic spectra measurements. The compounds are non-electrolyte in nitromethane and are magnetically dilute.
\end{abstract}

Keywords: Asymmetric Schiff-base, Heteroleptic complexes, Magnetically dilute, Non-electrolyte, Tetragonal geometry.

\section{Introduction}

Metal complexes of Schiff bases are extensively studied due to synthetic flexibility, selectivity and sensitivity towards a variety of metal atoms ${ }^{1}$. They are found useful in catalysis, in medicine as antibiotics and anti-inflammatory agents and in the industry as anticorrosion ${ }^{2-8}$. Literature is abundant on physico-chemical properties of various symmetrical Schiff bases and chelates with their pyridine, 2,2'-bipyridine and 1,10-phenanthroline adducts ${ }^{9-13}$, while comparatively little is known on asymmetric Schiff-base complexes and their heteroleptic analogs with triphenyl phosphine and 2,2'-bipyridine ${ }^{14-19}$. Consequently, my findings on the asymmetric Schiff-base ligand (derived from condensation of 1-phenyl-1,3-butanedione, ethylenediamine and 2-hydroxy4-methoxy benzophenone), its $\mathrm{VO}(\mathrm{IV}), \mathrm{Ni}(\mathrm{II})$ and $\mathrm{Cu}(\mathrm{II})$ complexes and heteroleptic analogs with triphenyl phosphine and 2,2'-bipyridine are hereby presented. All these compounds with the ligand (Figure 1) are new, being reported for the first time. 


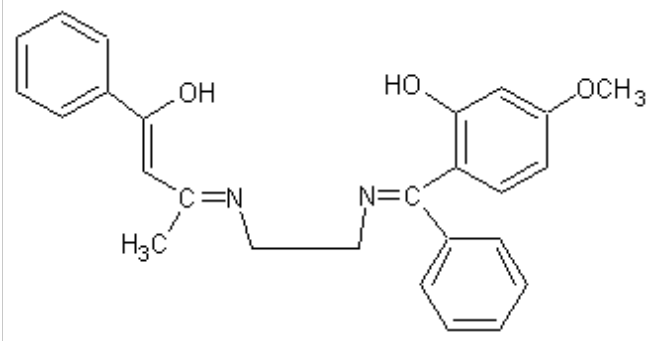

Figure 1. The structural formula the ligand

\section{Experimental}

Reagent grade 1-phenyl-1,3-butanedione, 2-hydroxy-4-methoxybenzophenone, ethylenediamine were obtained from Aldrich and used as received while vanadyl sulphate monohydrate, nickel(II) acetate tetrahydrate and copper(II) acetate monohydrate were available from BDH chemicals. Solvents were purified by standard methods ${ }^{20}$.

The elemental analyses $\mathrm{C}, \mathrm{H}$ and $\mathrm{N}$ were determined by Microanalytical Laboratory of Dipartimento di Scienze Chimiche, Universita di Trieste, Italy. Nickel and copper were determined titrimetrically and oxovanadium(IV) was estimated gravimetrically ${ }^{21}$. The IR spectra of the compounds were recorded on a Perkin-Elmer 2000 FTIR spectrophotometer, as $\mathrm{KBr}$ discs in the range $4000-400 \mathrm{~cm}^{-1}$ while the solid reflectance spectra were measured on a Unicam Helios $\gamma$-spectrophotometer. Magnetic susceptibilities were measured on Johnson Matthey magnetic susceptibility balance and diamagnetic corrections were calculated using Pascal's constant ${ }^{22}$ while conductivity measurements were measured using a MC-1, Mark V conductivity meter with a cell constant of 1.0 .

\section{Syntheses}

\section{[HO $\left.\left(\mathrm{C}_{6} \mathrm{H}_{3}\left(\mathrm{OCH}_{3}\right) \mathrm{C}\left(\mathrm{C}_{6} \mathrm{H}_{5}\right): \mathrm{N}\left(\mathrm{CH}_{2}\right)_{2} \mathrm{~N}: \mathrm{C}\left(\mathrm{CH}_{3}\right) \mathrm{CH}: \mathrm{C}\left(\mathrm{C}_{6} \mathrm{H}_{5}\right) \mathrm{OH}\right)\right]$, $\left(\mathrm{H}_{2} \mathrm{~L}\right)$}

The ligand was prepared by modification of a literature method ${ }^{14}$. A mixture of $0.1 \mathrm{~mol}$ $(6.00 \mathrm{~g} ; 6.70 \mathrm{~mL})$ ethylenediamine, $0.1 \mathrm{~mol}(22.83 \mathrm{~g})$ 2-hydroxy-4-methoxybenzophenone and $0.1 \mathrm{~mol}(16.22 \mathrm{~g})$ of benzoyl acetone, in $100 \mathrm{~mL}$ of ethanol was refluxed for two hours. The reaction mixture was cooled in ice and the yellow product, which was first formed, was filtered and washed with ethanol and dried over anhydrous calcium chloride.

\section{Preparation of the metal complexes}

The various complexes were prepared by addition of $5 \mathrm{mmol}$ of $\mathrm{Ni}\left(\mathrm{CH}_{3} \mathrm{COO}\right)_{2} \cdot 4 \mathrm{H}_{2} \mathrm{O} \quad(1.24$ $\mathrm{g}), \mathrm{Cu}\left(\mathrm{CH}_{3} \mathrm{COO}\right)_{2} \cdot \mathrm{H}_{2} \mathrm{O}(1.00 \mathrm{~g})$ or $\mathrm{VOSO}_{4} \cdot \mathrm{H}_{2} \mathrm{O}(0.82 \mathrm{~g})$ in bits to a stirring $5 \mathrm{mmol}$ of the ligand $(2.21 \mathrm{~g})$ in $60 \mathrm{~mL}$ of dried methanol at room temperature (the Oxovanadyl mixture was buffered with $10 \mathrm{mmol}$ of triethyl amine $(1.08 \mathrm{~g}, 1.49 \mathrm{~mL})$. After stirring for thirty minutes, the resulting homogeneous solution of the complex was refluxed for $2 \mathrm{~h}$ and the precipitated solids were filtered, washed with methanol and dried over anhydrous calcium chloride.

\section{Preparation of 2, 2'-bipyridine and triphenyl phosphine heteroleptic complexes}

Triphenyl phosphine $(1.30 \mathrm{~g}, 5 \mathrm{mmol})$ or 2,2'-bipyridine $(0.79 \mathrm{~g}, 5 \mathrm{mmol})$ dissolved in 10 $\mathrm{mL}$ of ethanol was added slowly to a solution of the Schiff-base chelates, (2.50-2.54 g, 5 $\mathrm{mmol}$ ) in $30 \mathrm{~mL}$ of ethanol while stirring. The mixture was refluxed for $1 \mathrm{~h}$ and the product formed was filtered, washed with ethanol several times and dried under vacuum. 


\section{Results and Discussion}

The reactions of the various metal(II) Schiff bases and heteroleptic analogs can be represented by equations $1-3$. The compounds are formed in moderate yields (30-80\%). The general equation for the formation of the compounds is given below:

$$
\begin{aligned}
& \mathrm{M}\left(\mathrm{CH}_{3} \mathrm{COO}\right)_{2} \mathrm{x} \mathrm{H}_{2} \mathrm{O}+\mathrm{H}_{2} \mathrm{~L} \longrightarrow \mathrm{ML}+2 \mathrm{CH}_{3} \mathrm{COOH}+\mathrm{x} \mathrm{H}_{2} \mathrm{O} \\
& \quad(\text { Where } \mathrm{M}=\mathrm{Cu}(\mathrm{II})\{\mathrm{x}=1\} ; \mathrm{Ni}(\mathrm{II})\{\mathrm{x}=4\}) \\
& \mathrm{VOSO}_{4} \cdot \mathrm{H}_{2} \mathrm{O}+\mathrm{H}_{2} \mathrm{~L}+2\left(\mathrm{C}_{2} \mathrm{H}_{5}\right)_{3} \mathrm{~N} \longrightarrow \mathrm{VOL}+\left\{\mathrm{NH}\left(\mathrm{C}_{2} \mathrm{H}_{5}\right)_{3}\right\}_{2} \mathrm{SO}_{4}+\mathrm{H}_{2} \mathrm{O}
\end{aligned}
$$

The reactions of the metal(II) Schiff bases with triphenyl phosphine/ 2, 2'-bipyridine in ethanol to give the heteroleptic complexes is as shown below:

$$
\mathrm{ML}+\mathrm{A} \longrightarrow \mathrm{ML}(\mathrm{A})
$$

(Where $\mathrm{M}=\mathrm{VO}(\mathrm{IV}), \mathrm{Ni}(\mathrm{II}), \mathrm{Cu}(\mathrm{II}) ; \mathrm{A}=$ triphenyl phosphine/ 2, 2'-bipyridine).

The $\mathrm{C}, \mathrm{H}$ and $\mathrm{N}$ data, percentage yields and melting points are presented in Table 1 . The molar conductances of the compounds that dissolved in nitromethane were below 15.00

\begin{tabular}{|c|c|c|c|c|c|c|c|c|c|}
\hline \multirow{2}{*}{$\begin{array}{l}\text { Compound } \\
\text { (Empirical } \\
\text { formula) }\end{array}$} & \multirow{2}{*}{ 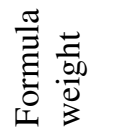 } & \multirow{2}{*}{$\frac{7}{\stackrel{0}{0}}$} & \multirow[t]{2}{*}{$\begin{array}{l}\text { M.pt } \\
{ }^{\circ} \mathrm{C}\end{array}$} & \multirow{2}{*}{$\begin{array}{c}\text { Anal. } \\
\mathrm{C}\end{array}$} & \multirow{2}{*}{$\begin{array}{c}\text { found } \\
\mathrm{H}\end{array}$} & \multicolumn{2}{|c|}{ (Cal) \% } & \multirow{2}{*}{$\begin{array}{l}\Lambda_{\mathrm{m}} \\
\Omega \mathrm{cm}^{2} \\
\mathrm{~mol}^{-1}\end{array}$} & \multirow[t]{2}{*}{$\begin{array}{l}\mu_{\mathrm{eff}} \\
\text { (B.M) }\end{array}$} \\
\hline & & & & & & $\mathrm{N}$ & M & & \\
\hline $\begin{array}{l}\mathrm{H}_{2} \mathrm{~L} \\
\left(\mathrm{C}_{26} \mathrm{H}_{26} \mathrm{~N}_{2} \mathrm{O}_{3}\right)\end{array}$ & 442.76 & 70 & $138-139$ & $\begin{array}{l}70.50 \\
(70.53)\end{array}$ & $\begin{array}{l}5.92 \\
(5.92)\end{array}$ & $\begin{array}{l}6.34 \\
(6.33)\end{array}$ & - & - & - \\
\hline $\begin{array}{l}{[\mathrm{VOL}]} \\
\left(\mathrm{VO}\left(\mathrm{C}_{26} \mathrm{H}_{24} \mathrm{~N}_{2} \mathrm{O}_{3}\right)\right.\end{array}$ & 507.68 & 80 & $234-236$ & $\begin{array}{l}61.50 \\
(61.51)\end{array}$ & $\begin{array}{l}4.79 \\
(4.77)\end{array}$ & $\begin{array}{l}5.54 \\
(5.52)\end{array}$ & $\begin{array}{l}10.02 \\
(10.03)\end{array}$ & 14.00 & 1.74 \\
\hline $\begin{array}{l}{\left[\mathrm{VOL}\left(\mathrm{P}(\mathrm{Ph})_{3}\right)\right]} \\
\left(\mathrm{VO}\left(\mathrm{C}_{44} \mathrm{H}_{39} \mathrm{~N}_{2} \mathrm{O}_{3} \mathrm{P}\right)\right.\end{array}$ & 769.97 & 60 & $211-213$ & $\begin{array}{l}68.62 \\
(68.64)\end{array}$ & $\begin{array}{l}5.00 \\
(5.01)\end{array}$ & $\begin{array}{l}3.62 \\
(3.64)\end{array}$ & $\begin{array}{l}6.67 \\
(6.62)\end{array}$ & 12.00 & 1.75 \\
\hline $\begin{array}{l}{[\mathrm{VOL}(\text { bipy })]} \\
\left(\mathrm{VO}\left(\mathrm{C}_{36} \mathrm{H}_{32} \mathrm{~N}_{4} \mathrm{O}_{3}\right)\right.\end{array}$ & 663.87 & 60 & $236-238$ & $\begin{array}{l}65.11 \\
(65.13)\end{array}$ & $\begin{array}{l}4.80 \\
(4.82)\end{array}$ & $\begin{array}{l}8.42 \\
(8.44)\end{array}$ & $\begin{array}{l}7.66 \\
(7.67)\end{array}$ & 10.00 & 1.76 \\
\hline $\begin{array}{l}{[\mathrm{NiL}]} \\
\left(\mathrm{Ni}\left(\mathrm{C}_{26} \mathrm{H}_{24} \mathrm{~N}_{2} \mathrm{O}_{3}\right)\right.\end{array}$ & 499.45 & 80 & $205-206$ & $\begin{array}{l}62.50 \\
(62.53)\end{array}$ & $\begin{array}{l}4.83 \\
(4.84)\end{array}$ & $\begin{array}{l}5.60 \\
(5.61)\end{array}$ & $\begin{array}{l}11.80 \\
(11.75)\end{array}$ & 12.00 & 0 \\
\hline $\begin{array}{l}{\left[\mathrm{NiL}\left(\mathrm{P}(\mathrm{Ph})_{3}\right) \mathrm{H}_{2} \mathrm{O}\right]} \\
\mathrm{Ni}\left(\mathrm{C}_{44} \mathrm{H}_{41} \mathrm{~N}_{2} \mathrm{O}_{4} \mathrm{P}\right)\end{array}$ & 779.76 & 50 & $210-211$ & $\begin{array}{l}67.75 \\
(67.78)\end{array}$ & $\begin{array}{l}5.32 \\
(5.30)\end{array}$ & $\begin{array}{l}3.60 \\
(3.59)\end{array}$ & $\begin{array}{l}7.56 \\
(7.53)\end{array}$ & 11.00 & 3.20 \\
\hline $\begin{array}{l}{[\mathrm{NiL}(\text { bipy })]} \\
\left(\mathrm{Ni}\left(\mathrm{C}_{36} \mathrm{H}_{32} \mathrm{~N}_{4} \mathrm{O}_{3}\right)\right.\end{array}$ & 655.64 & 30 & $230-231$ & $\begin{array}{l}65.93 \\
(65.95)\end{array}$ & $\begin{array}{l}4.86 \\
(4.88)\end{array}$ & $\begin{array}{l}8.56 \\
(8.55)\end{array}$ & $\begin{array}{l}8.98 \\
(8.96)\end{array}$ & 9.00 & 3.27 \\
\hline $\begin{array}{l}{[\mathrm{CuL}]} \\
\left(\mathrm{Cu}\left(\mathrm{C}_{26} \mathrm{H}_{24} \mathrm{~N}_{2} \mathrm{O}_{3}\right)\right.\end{array}$ & 504.29 & 80 & $240-242$ & $\begin{array}{l}61.94 \\
(61.93)\end{array}$ & $\begin{array}{l}4.79 \\
(4.80)\end{array}$ & $\begin{array}{l}5.57 \\
(5.56)\end{array}$ & $\begin{array}{l}12.80 \\
(12.60)\end{array}$ & 13.12 & 1.98 \\
\hline $\begin{array}{l}{\left[\mathrm{CuL}\left(\mathrm{P}(\mathrm{Ph})_{3}\right) \mathrm{H}_{2} \mathrm{O}\right]} \\
\left(\mathrm{Cu}\left(\mathrm{C}_{44} \mathrm{H}_{41} \mathrm{~N}_{2} \mathrm{O}_{4} \mathrm{P}\right)\right.\end{array}$ & 784.60 & 60 & $220-221$ & $\begin{array}{l}67.34 \\
(67.36)\end{array}$ & $\begin{array}{l}5.30 \\
(5.27)\end{array}$ & $\begin{array}{l}3.57 \\
(3.57)\end{array}$ & $\begin{array}{l}10.00 \\
(10.05)\end{array}$ & 11.00 & 2.03 \\
\hline $\begin{array}{l}{[\mathrm{CuL}(\text { bipy })]} \\
\left(\mathrm{Cu}\left(\mathrm{C}_{36} \mathrm{H}_{32} \mathrm{~N}_{4} \mathrm{O}_{3}\right)\right.\end{array}$ & 660.48 & 60 & $238-239$ & $\begin{array}{l}65.60 \\
(65.50)\end{array}$ & $\begin{array}{l}4.85 \\
(4.84) \\
\end{array}$ & $\begin{array}{l}8.46 \\
(8.48)\end{array}$ & $\begin{array}{l}9.62 \\
(9.61)\end{array}$ & 10.00 & 2.07 \\
\hline
\end{tabular}
$\mathrm{ohm}^{-1} \mathrm{~cm}^{2} \mathrm{~mol}^{-1}$ indicating that they were non-electrolytes, since a value in the range 75-90 $\mathrm{ohm}^{-1} \mathrm{~cm}^{2} \mathrm{~mol}^{-1}$ is expected for a 1:1 electrolyte.

Table 1 Analytical Data for Compounds.

\section{Spectral study}

The ultraviolet spectra of the compounds are characterized by two peaks between $29.00-35.00$ and 40.00-50.00 kK respectively, assigned to $\pi-\pi^{*}$ transitions (of various origin) and charge transfer transition respectively ${ }^{14-16}$. The oxovanadium(IV) complex, electronic spectrum shows three absorption bands at $15.45,17.55$ and $26.50 \mathrm{kK}$ respectively, which is consistent with a fivecoordinate, square-pyramidal geometry and is assigned to $\mathrm{b}_{2 \rightarrow} \mathrm{e}^{*}{ }_{\pi}$, (band I), $\mathrm{b}_{2 \rightarrow} \mathrm{b}_{1}$ (band II) and 
$\mathrm{b}_{2 \rightarrow} \mathrm{a}_{1}$ (band III) transitions. The heteroleptic analogs, on the other hand display one to two bands at 14.05 and $18.35-19.00 \mathrm{kK}$ which is indicative of a six-coordinate tetragonal (octahedral) geometry ${ }^{24}$. The Ni(II) complex has two absorption bands at 18.05 and $22.70 \mathrm{kK}$, typical of a 4-coordinate square planar geometry and is assigned to ${ }^{1} \mathrm{~A}_{1 \mathrm{~g}} \rightarrow{ }^{1} \mathrm{~B}_{1 \mathrm{~g}}$ and ${ }^{1} \mathrm{~A}_{1 \mathrm{~g}} \rightarrow{ }^{1} \mathrm{~A}_{2 \mathrm{~g}}$ transitions. The heteroleptic complexes, however, have three absorption bands between 18.10-18.25, 22.4223.00 and 24.04-24.89kK respectively, assigned to ${ }^{3} \mathrm{~A}_{2 \mathrm{~g}}(\mathrm{~F}) \rightarrow{ }^{3} \mathrm{~T}_{1 \mathrm{~g}}(\mathrm{~F})\left(v_{2}\right)$ and ${ }^{3} \mathrm{~A}_{2 \mathrm{~g}}(\mathrm{~F}) \rightarrow{ }^{3} \mathrm{~T}_{1 \mathrm{~g}}(\mathrm{P})$ $\left(v_{3}\right)$ transitions of a six-coordinate octahedral geometry ${ }^{14-15}$.

The copper(II) complex studied, displays two bands at 18.05 and $23.81 \mathrm{kK}$, assigned to ${ }^{2} \mathrm{~B}_{1 \mathrm{~g}} \rightarrow{ }^{2} \mathrm{~A}_{1 \mathrm{~g}}$ and ${ }^{2} \mathrm{~B}_{1 \mathrm{~g}} \rightarrow{ }^{2} \mathrm{E}_{1 \mathrm{~g}}$ transitions of 4 -coordinate square planar geometry while the heteroleptic analogs have an unsymmetrical band around $17.69 \mathrm{kK}$ which is indicative of a six-coordinate tetragonal (octahedral) arrangement of the ligands around the copper ion ${ }^{24}$.

\section{Infrared Spectra}

The strong band at $3300 \mathrm{~cm}^{-1}$, which is conspicuously absent in the spectra of the complexes, is assigned as $v \mathrm{OH}$ stretching frequency in the ligand, which indicatives deprotonation and involvement of the enol $\mathrm{O}$ in chelation. The uncoordinated $\mathrm{C}=\mathrm{N}$ and $\mathrm{C}=\mathrm{C}$ stretching vibrations occur as coupled bands expectedly in the ligand at 1606-1542 $\mathrm{cm}^{-1}$ and are bathochromic shifted to $1600-1513 \mathrm{~cm}^{-1}$ on coordination to the metal ions ${ }^{18-19}$, indicative of the involvement of $\mathrm{N}$ and $\mathrm{O}$ donor atoms of $\mathrm{C}=\mathrm{N}$ and enol groups respectively, in coordination to the metal ions. In heteroleptic complexes, these bands are hypsochromic shifted to $1608-1516 \mathrm{~cm}^{-1}$ which is indicative of a stronger M-P/M-N (base) bonds in them ${ }^{19}$. The $v(\mathrm{~V}=\mathrm{O})$ bands appeared very strong between $940-980 \mathrm{~cm}^{-1}$ while those due to $v(\mathrm{M}-\mathrm{O})$ and $v(\mathrm{M}-\mathrm{N}) / v(\mathrm{M}-\mathrm{P})$ were observed $^{14-15}$ at 494-444 and 599-525 $\mathrm{cm}^{-1}$ (Table 2).

Table 2. Infrared and Electronic Spectral Data of the Complexes.

\begin{tabular}{|c|c|c|c|c|c|}
\hline Compound & $v \mathrm{OH}$ & $\begin{array}{c}v(\mathrm{C}=\mathrm{N}) \\
+ \\
v(\mathrm{C}=\mathrm{C})\end{array}$ & $\begin{array}{c}v(\mathrm{M}-\mathrm{N}) / \\
(\mathrm{M}-\mathrm{P})\end{array}$ & $v(\mathrm{M}-\mathrm{O})$ & $\lambda \max (\mathrm{kK})$ \\
\hline $\mathrm{H}_{2} \mathrm{~L}$ & $3300 \mathrm{~s}$ & $\begin{array}{l}1606 \mathrm{~s} \\
1542 \mathrm{~s}\end{array}$ & - & - & 29.0035 .0042 .0049 .00 \\
\hline [VOL] & - & $\begin{array}{l}1583 \mathrm{~s} \\
1519 \mathrm{~s}\end{array}$ & $525 \mathrm{~s}$ & $444 \mathrm{~s}$ & $15.45 \quad 17.5526 .5033 .30 \quad 41.00$ \\
\hline$\left[\operatorname{VOL}\left(\mathrm{P}(\mathrm{Ph})_{3}\right)\right]$ & - & $\begin{array}{l}1600 \mathrm{~s} \\
1581 \mathrm{~s}\end{array}$ & $542 \mathrm{~s}$ & $494 s$ & $\begin{array}{llll}14.05 & 18.35 & 32.00 & 40.00\end{array}$ \\
\hline [VOL(bipy)] & - & $\begin{array}{l}1601 \mathrm{~s} \\
1582 \mathrm{~s}\end{array}$ & $559 \mathrm{~s}$ & $465 \mathrm{~m}$ & $\begin{array}{lll}19.00 & 31.00 & 40.00\end{array}$ \\
\hline$[\mathrm{NiL}]$ & - & $\begin{array}{l}1600 \mathrm{~s} \\
1513 \mathrm{~s}\end{array}$ & $595 \mathrm{~s}$ & $473 \mathrm{~s}$ & $18.0522 .7030 .00 \quad 41.00$ \\
\hline$\left[\mathrm{NiL}\left(\mathrm{P}(\mathrm{Ph})_{3}\right) \mathrm{H}_{2} \mathrm{O}\right]$ & $3500 \mathrm{~b}$ & $\begin{array}{l}1608 \mathrm{~s} \\
1518 \mathrm{~s}\end{array}$ & $599 m$ & $484 \mathrm{~s}$ & $18.1023 .0024 .04 \quad 34.0041 .00$ \\
\hline [NiL(bipy)] & - & $\begin{array}{l}1608 \mathrm{~s} \\
1516 \mathrm{~s}\end{array}$ & $559 \mathrm{~m}$ & $483 \mathrm{~m}$ & $\begin{array}{llll}18.25 & 22.42 & 24.8934 .00 & 41.00\end{array}$ \\
\hline$[\mathrm{CuL}]$ & - & $\begin{array}{l}1577 \mathrm{~s} \\
1513 \mathrm{~s}\end{array}$ & $595 \mathrm{~s}$ & $468 \mathrm{~s}$ & 18.0523 .8134 .0041 .00 \\
\hline$\left[\mathrm{CuL}\left(\mathrm{P}(\mathrm{Ph})_{3}\right) \mathrm{H}_{2} \mathrm{O}\right]$ & $3500 \mathrm{~b}$ & $\begin{array}{l}1589 \mathrm{~s} \\
1516 \mathrm{~s}\end{array}$ & $582 \mathrm{~m}$ & $451 \mathrm{~s}$ & 17.1931 .0041 .0 \\
\hline [CuL(bipy)] & - & $\begin{array}{l}1590 \mathrm{~s} \\
1517 \mathrm{~s}\end{array}$ & $595 \mathrm{~m}$ & $473 m$ & 18.1830 .0040 .00 \\
\hline
\end{tabular}

$\mathrm{b}=$ broad, $\mathrm{m}=$ medium, $\mathrm{s}=$ strong, $1 \mathrm{kK}=1000 \mathrm{~cm}^{-1}$ 


\section{Magnetic Moments}

Oxovanadium(IV) complexes are expected to have a moment of 1.73B.M, regardless of the geometry, when the orbital contribution is completely quenched by low symmetry fields. However, in the compounds studied a moment in the range 1.74-1.76 B.M is observed, indicative of monomeric compounds. In the $\mathrm{Ni}(\mathrm{II})$ compounds reported in this work, the complex is diamagnetic while the heteroleptic complexes have moment of 3.20 and 3.27 B.M, respectively. The former is indicative of a four coordinate, square planar geometry while the latter is suggestive of a six coordinate, octahedral geometry ${ }^{22}$. The magnetic moments of 1.98 - 2.07 B.M. is observed for the copper(II) compounds, which indicate that they are magnetically dilute and are higher than the spin-only value of 1.73 B.M. as a result of orbital contribution and spin-orbit coupling ${ }^{22}$.

\section{Conclusion}

The asymmetric Schiff-base ligand coordinates to the $\mathrm{VO}(\mathrm{IV}), \mathrm{Ni}(\mathrm{II})$ and $\mathrm{Cu}(\mathrm{II})$ ions in a tetradentate manner using the azomethine $\mathrm{N}$ and enol $\mathrm{O}$ atoms. The assignment of a 4coordinate, square planar for $\mathrm{Ni}$ and $\mathrm{Cu}$ complexes, a 5-coordinate square-pyramidal geometry for the $\mathrm{VO}(\mathrm{IV})$ complex and 6-coordinate octahedral geometry (Figure 2) for their heteroleptic analogs is corroborated by magnetic, infrared and electronic spectral measurements.<smiles>COc1ccc(C(=NCCN2CCN(C(C)=O)CC2)Oc2ccccc2)c(OC)c1</smiles>

()

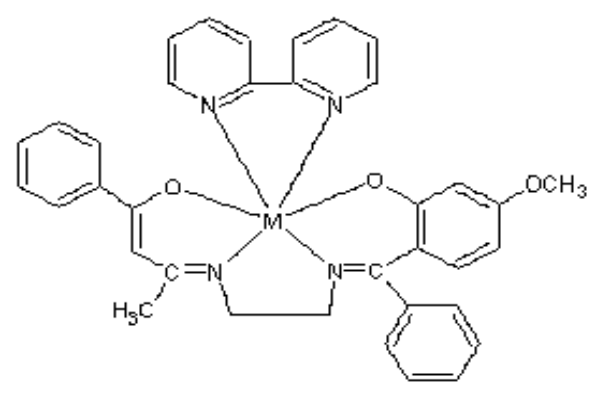

$M=v O(M), N i l l), C u(l i)$

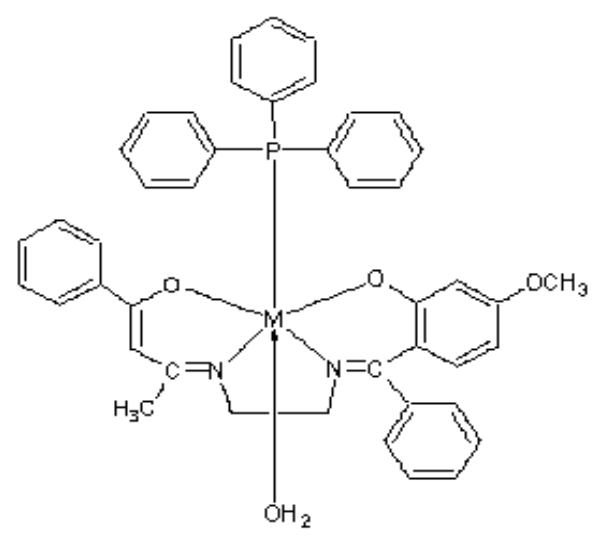

$M=N i|l| l, c u(I)$

(b)

(c)

Figure 2. The proposed coordination spheres of the Schiff-base Complexes (a) and their heteroleptic analogs (b and c). 


\section{Acknowledgement}

The author thanks Dipartimento di Scienze Chimiche, Universita di Trieste, Italy for the microanalysis and The Abdus Salam International Centre for Theoretical Physics (ICTP) and Swedish International Development Cooperation Agency (Sida) for support.

\section{References}

1. Spinu C and Kriza A, Acta Chim. Slov. 2000, 47, 179.

2. Sun B, Chen J, Hu, J Y and Li X, J Chin. Chem. Lett. 2001, 12(11), 1043.

3. Boghaei D M and Mohebi S, Tetrahedron. 2002, 58(26), 5357.

4. Liu J, Wu B, Zhang B and Liu Y Turk J. Chem. 2006, 30, 41.

5. Britovsek G J P, Gibson V V, Mastroianni S, Oakes D C H, Redshaw C, Solan G A, White A J P and Williams D J, Eur.J.Inorg.Chem. 2001, 2001(2), 431.

6. Budakoti A, Abid M and Azam A, Eur. J. Med. Chem. 2006, 41(1), 63.

7. Jin V X, Tan S I and Ranford J D, Inorg. Chim. Acta. 2005, 358(3), 677.

8. Mehta N K and Agarwala V S, Int. Corros. Cong. Proc. 1996, 13(319), 1.

9. Chohan Z H, Synth. React. Inorg. Met. Org. Chem. 2001, 31(1), 1.

10. Thangadurai T D and Natarajan. K, Trans. Met. Chem. 2001, 26, 500.

11. Jejurkar C R and Parik H K, Asian. J. Chem. 1997, 9(4), 624.

12. Felico R C, Dasilva G A, Ceridorio, L F and Dockal E R, Synth. React. Inorg. Met.Org. Chem. 1999, 29(2), 171.

13. Osowole A A, Woods J A O and Odunola O A, Synth. React. Inorg. Met. Org. Chem. 2003, 33(2), 167.

14. Kwiatoski E and Kwiatoski M, Inorg. Chim. Acta. 1980, 47(2), 197.

15. Boghaei D M and Mohebi S, J. Chem. Res. 2001, 6, 660.

16. Lashanizadegan M and Boghaei D M Synth. React. Inorg. Met.-Org. Chem. 2001, 31(8), 1519-1529.

17. Osowole A A, Kolawole G A and Fagade O E, Bull. Sci. Asso. Nig. 2004, 25, 57.

18. Osowole A A, Kolawole G A and Fagade O E, Synth. React. Inorg. Met. Org. Chem and Nano-Met. Chemistry. 2005, 35, 829.

19. Osowole A A, Kolawole G A and Fagade O E Int. J. Chem. 2005, 15(4), 237.

20. Vogel A I, A Textbook of Practical Organic Chemistry; Longman, 1978, 321.

21. Bassett J, Denney R C, Jeffery G H and Mendham J, Vogel's Textbook of Quantitative Inorganic Analysis; ELBS: London, 1978, 325.

22. Earnshaw A,The Introduction to Magnetochemistry, Academic Press:London,968, 80.

23. Fackler and J P Jr, Metal $\beta$-Ketoenolates Complexes In Progress in Inorganic Chemistry; Cotton F.A Ed.: Wiley Interscience, 1966,7, 361.

24. Lever A B P, Inorganic Electronic Spectroscopy; Elsevier: London, 1980, 481. 


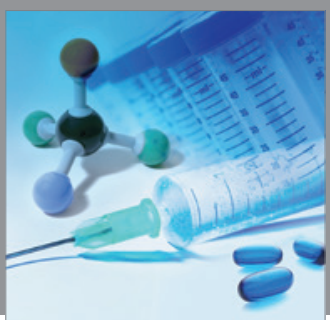

International Journal of

Medicinal Chemistry

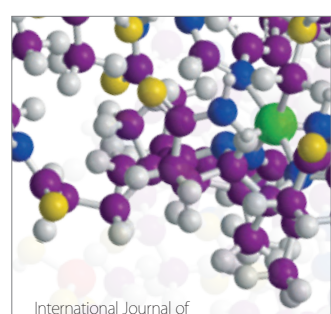

Carbohydrate Chemistry

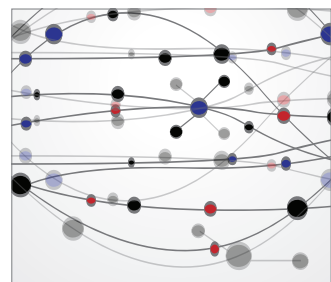

The Scientific World Journal
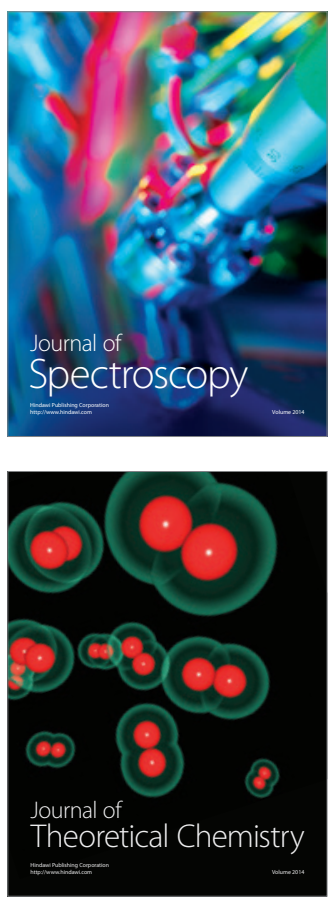
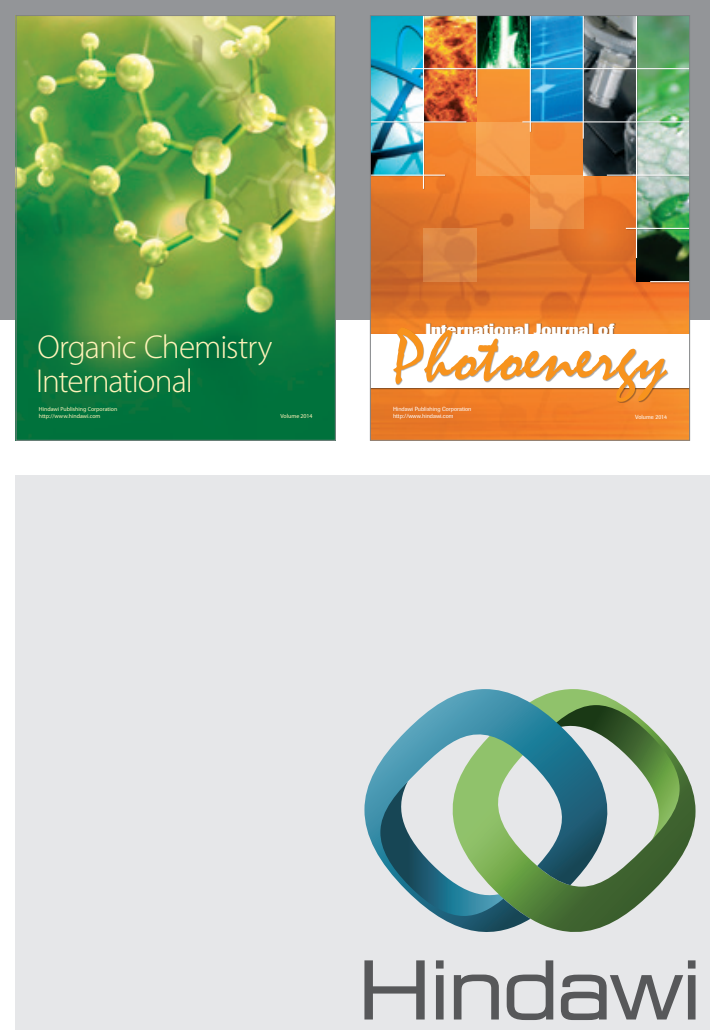

Submit your manuscripts at

http://www.hindawi.com
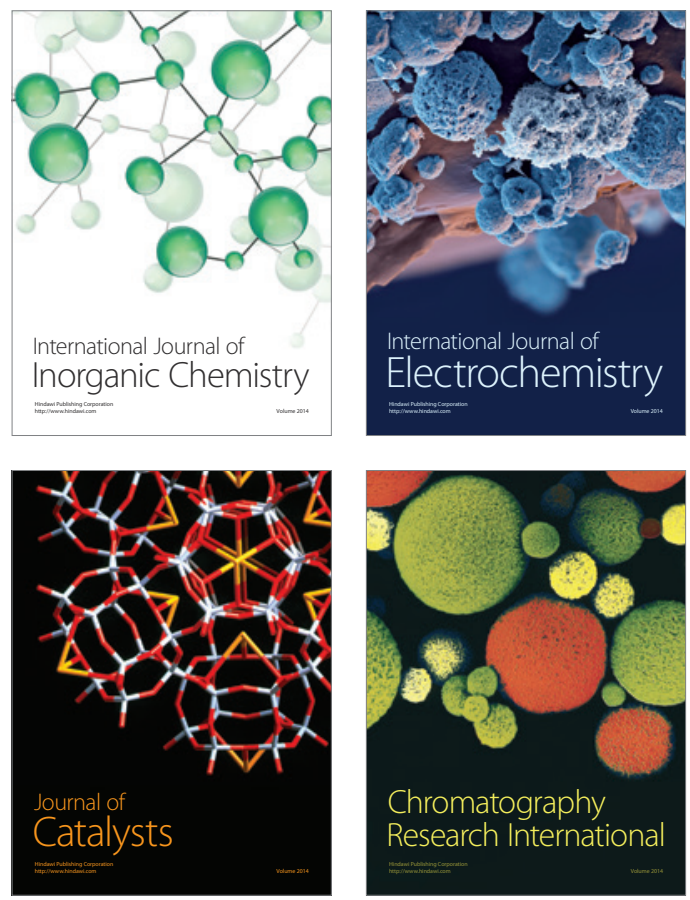
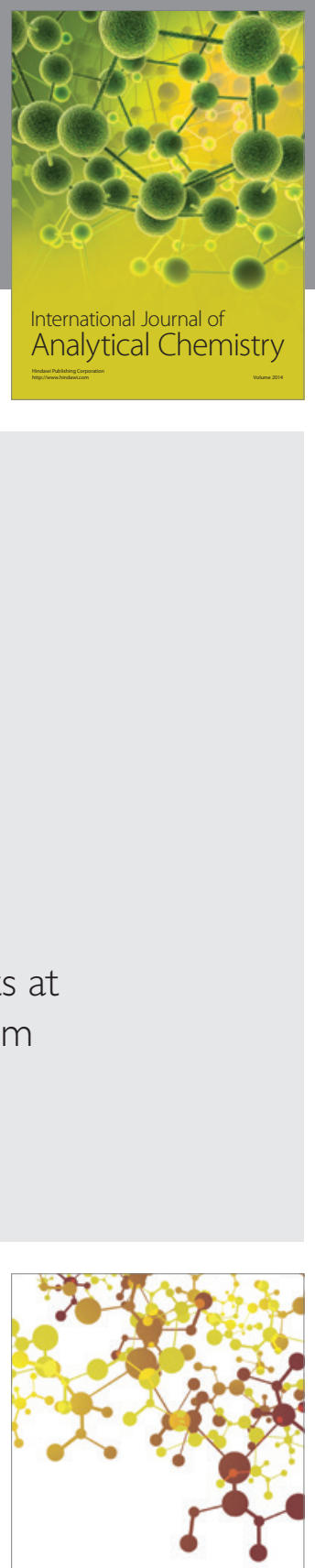

Journal of

Applied Chemistry
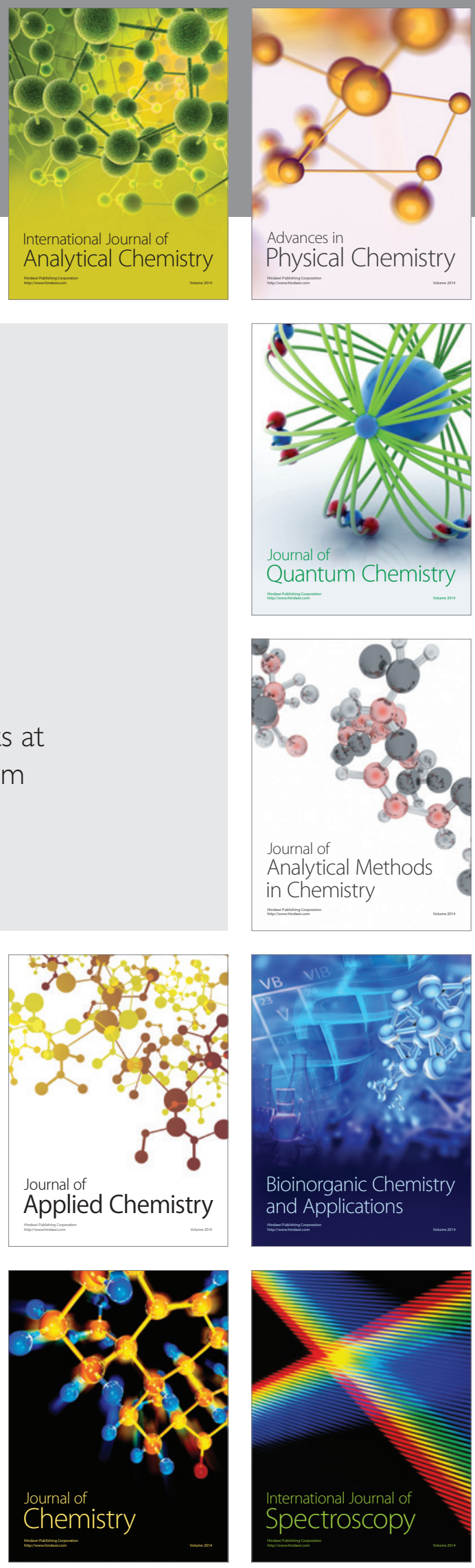